\title{
Erratum: Tracking the structural dynamics of proteins in solution using time-resolved wide-angle $\mathrm{X}$-ray scattering
}

Marco Cammarata, Matteo Levantino, Friedrich Schotte, Philip A Anfinrud, Friederike Ewald, Jungkweon Choi, Antonio Cupane, Michael Wulff \& Hyotcherl Ihee

Nat. Methods 5, 881-886 (2008); published online 21 September 2008; corrected after print 29 September 2008.

In the version of this article initially published, the time scale reported in the Figure $2 \mathrm{~d}$ legend is incorrect. The correct time scale should be $3 \mu$ s. Additionally, the time delay of $320 \mathrm{~ms}$ reported in Figure $5 \mathrm{~b}$ is incorrect. The correct time delay is $200 \mathrm{~ms}$. These errors have been corrected in the HTML and PDF versions of the article. 